Research note

\title{
The reproductive features of a mature female of the deep sea planktonic squid Galiteuthis glacialis (Cephalopoda: Cranchiidae) from the Southern Ocean

\author{
Vladimir Laptikhovsky \& Alexander Arkhipkin
}

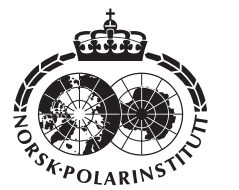

A mature female Galiteuthis glacialis (430 $\mathrm{mm}$ mantle length) was caught south of the Falkland Islands $\left(53^{\circ} \mathrm{S}, 58^{\circ} \mathrm{W}\right)$ at a depth of $976-1001 \mathrm{~m}$ over a bottom depth of 1582-2378 $\mathrm{m}$. A total of 8 spermatangia (15-19 $\mathrm{mm}$ in length) were found inserted into the mantle wall, which was of gelatinous consistency. Its ovary contained $3605 \pm 42$ oocytes, mostly $2.2-2.5 \mathrm{~mm}$ in length, and there were 21 ripe eggs $(3.0-3.2 \times 2.2-2.7 \mathrm{~mm})$ in the oviducts. Only one resorpting oocyte $(1.4 \mathrm{~mm})$ was found. This is the only description of a mature female of this species, though two spent females have been previously described and three more mentioned by other authors.

V. Laptikhovsky \& A. Arkhipkin, Falkland Islands Government Fisheries Dept., Box 598, Stanley, Falkland Islands,vlaptikhovsky@fisheries.gov.fk.

Squid of the family Cranchiidae are among the most abundant squids in the World Ocean. Juveniles and immature cranchiids inhabit mainly epipelagic and mesopelagic waters, whereas adults descend upon maturation into bathypelagic waters (Nesis 1985). This has limited the capture of mature animals as deepwater pelagic trawls are rarely performed during research cruises. Data on the reproductive biology of cranchiids remain extremely scarce. To date, the only full description of the reproductive system of a mature prespawning cranchiid female was of Teuthowenia pellucida (Voss 1985).

The squid Galiteuthis glacialis (Chun 1906) is numerous south of the Antarctic Polar Front (Nesis 1985; Nesis et al. 1998). As with other cranchiids, adults occur in the lower mesopelagic and bathypelagic zones (Nesis et al. 1998), whereas post-spawning moribund squids become positively buoyant and appear near the surface, where they fall prey to seabirds (Croxall \& Prince 1996). Mature females of G. glacialis with spermatophores embedded in their mantles have been caught twice between 800 and $1800 \mathrm{~m}$ depth (McSweeny 1978; Lu \& Williams 1994), but were not been described. Recently, two dead spent females (425 and $475 \mathrm{~mm}$ mantle length) were collected from an ice hole over ca. $1900 \mathrm{~m}$ depth in the western part of the Weddell Sea (Nesis et al. 1998).

Mature females of this species have not been described yet. This report describes the reproductive system of a mature female which was caught by the RV Dorada using a semi-pelagic $3 \mathrm{hr}$ Engel trawl on 1 November 2002 at a depth horizon of 976-1001 m over bottom depths of 1582-2378 $\mathrm{m}$ at $53^{\circ} 22.1^{\prime}-53^{\circ} 29.0^{\prime} \mathrm{S}, 58^{\circ} 16.7^{\prime}-58^{\circ} 03^{\prime} 9 \mathrm{~W}$. The animal, which had a mantle length of 430 $\mathrm{mm}$, had no head-it had probably been picked off by an albatross during hauling, but the body was not seriously damaged. The squid was preserved in $10 \%$ buffered formalin solution and then transferred into $70 \%$ ethanol. During examination, three samples (total $2.1 \mathrm{~g}$ ) were taken from the intact part of the ovary (8.8 g) and all oocytes were counted. Another part of 


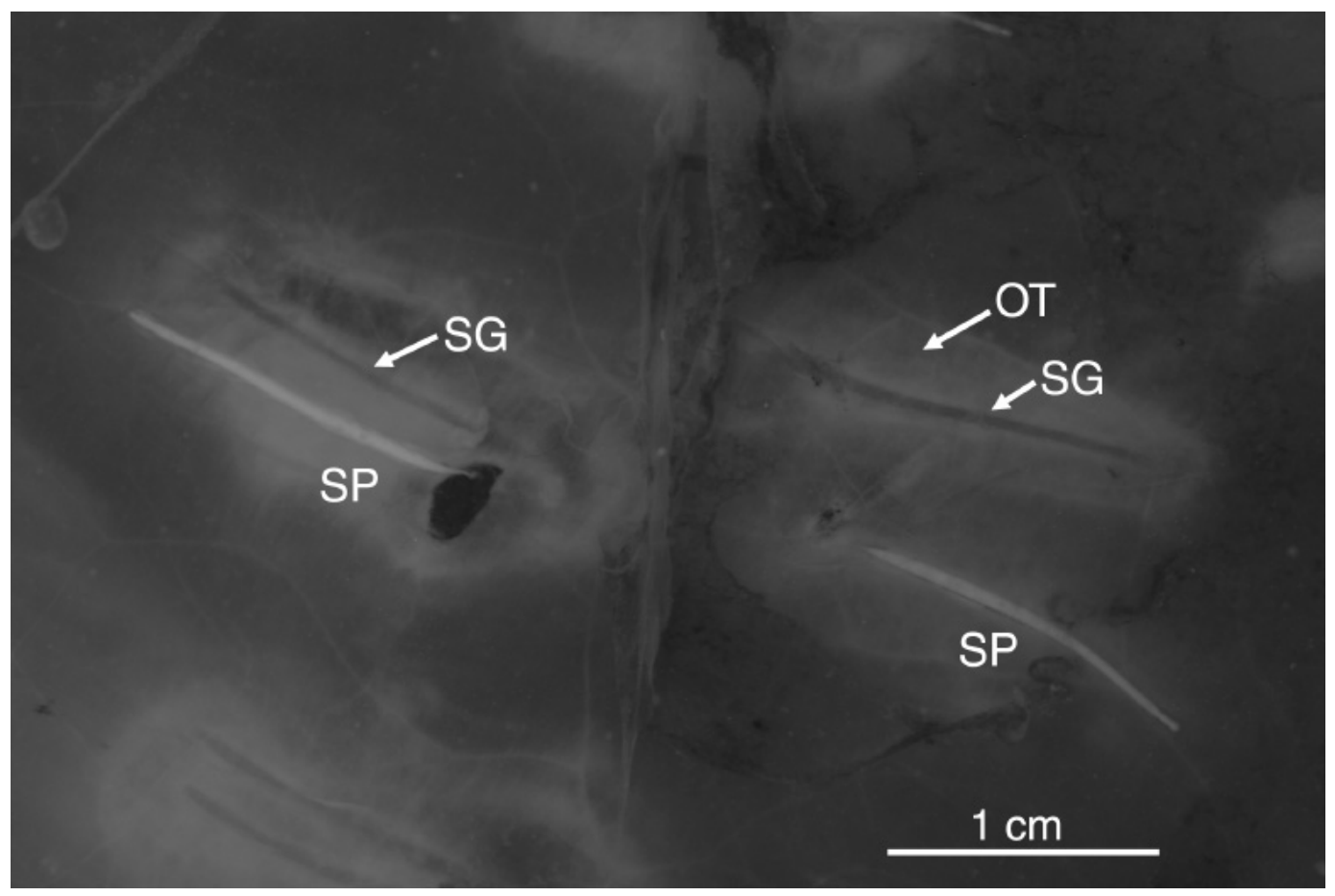

Fig. 1. Implanted spermatophores (spermatangia) in the mantle wall of a mature female Galiteuthis glacialis. The skin near the spermatangia is partially removed. Abbreviations: SP-spermatangia, SG-vacant grooves of spermatangia, OT-opaque tissue surrounding spermatangia.

the gonad $(6.0 \mathrm{~g})$ was fragmented due to ovary fragility (Nesis et al. 1998), but no part of the ovary was lost. All oocytes from the fragmented part were counted by eye. Oocytes from a random sample of 106 oocytes were measured along the major axis within $0.1 \mathrm{~mm}$. Among others, two ripe eggs and one resorpting oocyte were found in the intact part of the ovary.

The mature female had a spindle-shaped gelatinous mantle with an attenuated posterior tip and oval-shaped fin as has been observed in spent females (Nesis et al. 1998). The skin of the body was mostly intact, with a few marks from the trawl mesh. The mantle was covered by pale brown and whitish stripes and blotches. Halfway between the anterior and posterior parts of the mantle, eight spermatangia of $15-19 \mathrm{~mm}$ length were found inserted into the mantle wall under the skin (Fig. 1). They were parallel to the longitudinal body axis at the left side of the body and appeared to be from a single copulation. Mantle tissue around each spermatangium was more opaque. In some places, there were similar opaque traces with a groove corresponding to lost or spent spermatangium (Fig. 1). However, as there was a lack of empty follicular sheaths in the ovary it is quite unlikely this female had been spawning. Spermatangia placement on the body was different from that observed (near anterior margin of the mantle) in the spent females from the Weddel Sea. The stomach was empty, without any traces of food. Similar to the spent females, the digestive gland was spindle-shaped and rigid (Nesis et al. 1998). There were 21 ripe eggs of $3.0-3.2 \times 2.2-2.7 \mathrm{~mm}$ in the oviducts. The ovary (total weight $14.8 \mathrm{~g}$ ) contained $3605 \pm 42$ oocytes. Empty follicles were not found probably because of the relatively small numbers of ovulated eggs (21). Only one resorbing egg (1.4 mm length) was noticed among a subsample of 1967 counted oocytes. The oocytes of 2.2-2.5 mm predominated $(96.6 \%)$ in the ovary (Fig. 2), indicating synchronous egg release.

Our data on egg size and fecundity are consistent with those from the two spent females from the Weddell Sea, with residual egg size of $3.3 \times 2.4 \mathrm{~mm}$ and ovaries containing 3400 and 2100 empty follicles. In contrast to our specimen, 
Fig. 2. Length-frequency distribution of oocytes in the ovary of a mature female Galiteuthis glacialis.

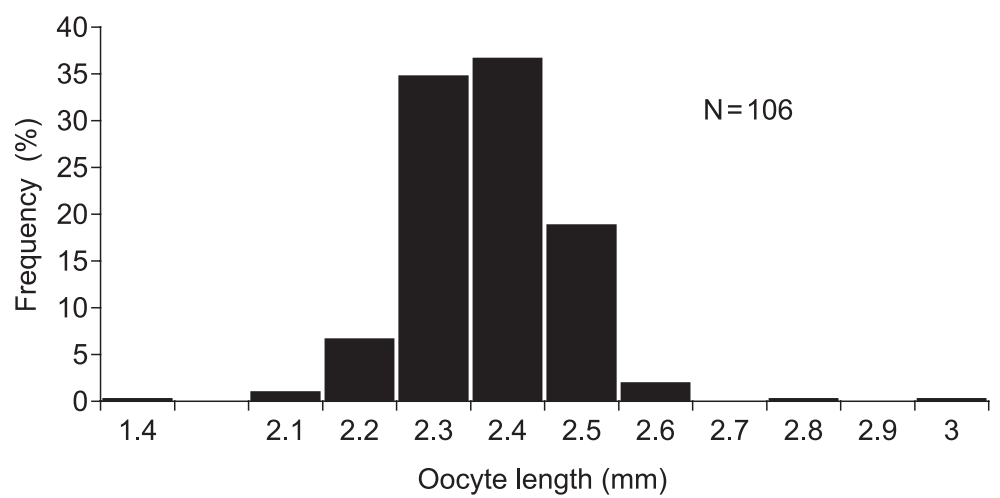

the spent females from the Weddell Sea had a large amount of small resorpting oocytes of 0.9-1.4 mm (10600-20900), indicating high initial potential fecundity. The resorption of the potential fecundity during female maturation, when up to $85 \%$ of the initial oocyte stock can disappear, is known for the other deep sea pelagic squids of the family Histioteuthidae (Laptikhovsky 2001). One of the reasons for this resorption could be an adjustment of potential fecundity to the actual body size attained by the adult female. Big differences in the number of resorbing oocytes between the Falkland and Weddell Sea G. glacialis females sharply contrasted with nearly equal actual fecundity in all females, and could indicate differences in the initial potential fecundity between sub-Antarctic and Antarctic populations.

\section{References}

Croxall, J. P. \& Prince, P. A. 1996: Cephalopods as a prey. I. Seabirds. Phil. Trans. R. Soc. Lond. Ser. B 351, 1023-1043. Laptikhovsky, V. V. 2001: First data on ovary maturation and fecundity in the squid family Histioteuthidae. Sci. Mar. 65, $127-129$.

Lu, C. C. \& Williams, R. 1994: Contribution to the biology of squids in the Prydz Bay region, Antarctica. Antarct. Sci. 6, 223-229.

McSweeney, E. S. 1978: Systematics and morphology of the Antarctic cranchiid squid Galiteuthis glacialis (Chun). Biol. Antarct. Seas, VII Antarct. Res. Ser. 7, 1-39.

Nesis, K N. 1985: Okeanicheskie golovonogie molluski: rasprostranenie, zhiznennye formy $i$ evolutsia. (Oceanic cephalopod molluscs: distribution, life forms and evolution.) Moscow: Nauka Press.

Nesis, K. N., Nigmatullin, C. M. \& Nikitina, I. V. 1998: Spent females of deepwater squid Galiteuthis glacialis under the ice at the surface of the Weddell Sea (Antarctic). J. Zool. 244, 185-200.

Voss, N. A. 1985: Systematics, biology and biogeography of the cranchiid cephalopod genus Teuthowenia (Oegopsida). Bull. Mar. Sci. 36, 1-85. 